\title{
Impact of Spraying Lithovit and Different Irrigation Levels on Growth, Blooming and Fruit Setting of Manzanello Olive (Olea Europaea L.) Cultivar
}

\author{
${ }^{1,2}$ Dobiea I.M., H.E.M. El-Badawy ${ }^{1}$, S.F. El-Gioushy ${ }^{1}$ and A.A.H. Hegazy ${ }^{2}$ \\ ${ }^{1}$ Horticulture Department, Faculty of Agriculture, Benha University, Egypt. \\ ${ }^{2}$ Plant Production Department, Desert Research Center, Egypt. \\ Received: 07 Oct. 2019 / Accepted 20 Nov. 2019 / Publication date: 30 Nov. 2019
}

\begin{abstract}
Water stress is one of the main challenges which constrain olive cultivation in reclaimed area in Egypt. It can impair the growth and production performance of olives. Many investigations recommended spraying Lithovit to reduce the effect of water stress. We believe that we have designed an innovative solution to follow up the effect of spraying Lithovit $\left(\mathrm{Ca} \mathrm{CO}_{3} \& \mathrm{Mg} \mathrm{CO}_{3}\right)$ on olive trees which exposure to different irrigation levels. Four concentrations of Lithovit were sprayed on olive (Olea europaea var. Manzanello) trees (0, 2, 4 and $6 \mathrm{~g} / \mathrm{L})$ under three irrigation levels $(50,75$ and $100 \%$ of evapotranspiration for crop "ETc") during 2017, 2018 seasons. Strong evidence of irrigation at 75\% of ETc was found on olive growth, blooming and fruit setting. It was the best irrigation level to balance between vegetative growth and blooming. Moreover, there were significant variations between spraying Lithovit at $2 \mathrm{~g} / \mathrm{L}$ and other concentrations on Blooming and fruit setting. Furthermore, the interaction between spraying Lithovit and irrigation levels cleared that spraying Lithovit at $2 \mathrm{~g} / \mathrm{L}$ and irrigation at $75 \%$ of ETc enhanced blooming and fruit setting. On the other hand irrigation at $100 \%$ of ETc with spraying Lithovit at $2 \mathrm{~g} / \mathrm{L}$ improved the vegetative characteristics.
\end{abstract}

Keywords: Olive, Manzanello, Lithovit ${ }^{\circledR}$, Irrigation Requrements, Growth, Blooming and Water stress

\section{Introduction}

Olive tree is a strategic tree, which grow in reclaimed areas, whereas planting the other crops in these areas is economically feasible. The environmental conditions play a major role in olives growth and productivity (Lavee et al., 1990).

Olive trees have been widely cultivated throughout the Mediterranean basin for around 5000 years. Olives can thrive and produce in arid, semi-arid and the new reclaimed areas. As it can resist abiotic potentials such as drought, fluctuation in temperature, salinity, drought (Xiloyannis et al., 1999 and Shaheen et al., 2011).

Previous studies indicated that water stress plays a major role in olives growth and productivity moreover "it impairs the performance of olives growth and production" besides supplying olives with water requirements increase vegetative growth, blooming and yield quantity and quality. On the other side, vegetative growth, blooming and yield quantity and quality decrease gradually with increasing water stress (Lavee et al., 1990; Xiloyannis et al., 1999; Chartzoulakis et al., 2000; Asik et al., 2014 and Tangu, 2014).

Spraying Lithovit"Lithovit ${ }^{\circledR}$ fertilizer is natural stone which grinded in special mills and converted to fine powder" as foliar application leads to decompose its particles and release among other substances, especially calcium oxide $(\mathrm{Ca} \mathrm{O})$ and carbon di oxide $\left(\mathrm{CO}_{2}\right)$ at high concentration in the intercellular compartment inside the leaves as well as on leaves surface which penetrate directly through the stomata (Kumar et al., 2013). The process of elevate $\mathrm{CO}_{2}$ in intercellular compartment and on leave surface lead to close stomata and photosynthesis continue efficiently due to diffused carbon dioxide inside the leaves, so plant decrease transpiration rate and reduce water requirement due to high drought tolerance (Bunce, 2003, Carmen et al., 2014 and Ainsworth and Rogers, 2007).

Previous studies revealed that olive growth and the quality and quantity of fruits reduce gradually with increasing water stress. On the other hand, supplying olives with water requirements improve the quality and quantity of fruits and vegetative characteristics (Shaheen et al., 2011 and Asik et al., 2014).

Thus, this study was initiated to follow up the effect of spraying Lithovit $\left(\mathrm{CaCO}_{3} \& \mathrm{Mg} \mathrm{CO}_{3}\right)$ with different levels of irrigation on Manzanello olive growth, blooming and fruit setting. 


\section{Materials and Methods}

This study was carried out at Wadi El-Natron in a sandy soil "Surface soil samples were taken and air dried for carrying out physical and chemical analysis which presented in the tables 1 and 2" of a private orchard at Wadi El-Natron, El Behera governorate, Egypt (30 31' 05" N and 30 07' 34" E). The experiment was started in December and continued during two successive growing seasons $(2017 \&$ 2018). It was investigated on Manzanello olive cultivar. Seventy-two bearing trees were selected and divided into 12 different treatments. Each treatment divided into three replicates and two trees for each of them. These selected trees were treated with three irrigation levels $(50,75$ and $100 \%$ of ETc) and four concentrations of Lithovit"Lithovit ${ }^{\circledR}$ fertilizer" $(0,2,4$ and $6 \mathrm{~g} / \mathrm{L})$ were sprayed as a foliar application in the first week of February, May, and August.

Table 1: Analysis of mechanical dry sieving of the orchard experimental soil

\begin{tabular}{cccccccc}
\hline Texture & Depth & $\begin{array}{c}\mathbf{1 - 2} \\
\mathbf{m m}\end{array}$ & $\begin{array}{c}\text { Coarse } \\
\text { sand }\end{array}$ & $\begin{array}{c}\text { Medium } \\
\text { sand }\end{array}$ & Fine sand & $\begin{array}{c}\text { Very fine } \\
\text { sand }\end{array}$ & $\begin{array}{c}\text { Silt }+ \\
\text { Clay }\end{array}$ \\
\hline Sandy soil & $0-60 \mathrm{~cm}$ & 7.5191 & 15.3507 & 38.1163 & 32.182 & 6.4756 & 0.3563 \\
\hline
\end{tabular}

Table 2: Chemical analysis of the orchard experimental soil

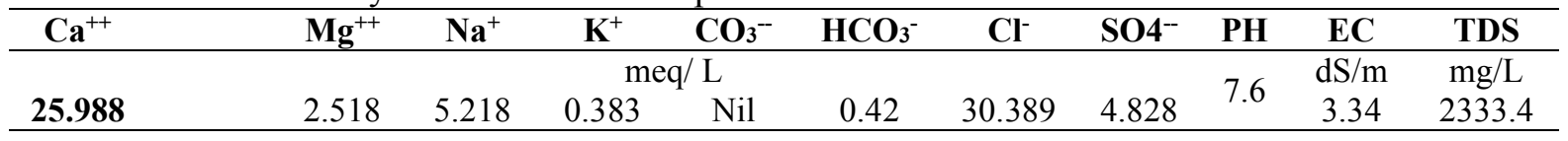

The following table presented chemical analysis of irrigation water sample, which taken from a well after two hours of starting operating.

Table 3: Analysis of irrigation water sample

\begin{tabular}{|c|c|c|c|c|c|c|c|c|c|c|}
\hline EC & TDS & PH & $\mathrm{Ca}^{++}$ & $\mathbf{M g}^{++}$ & $\mathbf{N a}^{+}$ & $\mathbf{K}^{+}$ & $\mathrm{CO}_{3}^{--}$ & $\mathrm{HCO}_{3}{ }^{-}$ & $\mathrm{SO}_{4}^{--}$ & $\mathrm{Cl}^{-}$ \\
\hline $\begin{array}{c}\mu \mathrm{SS} / \mathrm{cm} \\
1617\end{array}$ & $\begin{array}{l}\mathrm{Mg} / 1 \\
641.5\end{array}$ & 7.7 & 1.638 & $\begin{array}{c}\text { Cations } \\
1.467\end{array}$ & $\begin{array}{c}\mathrm{meq} / \mathrm{l} \\
8.696\end{array}$ & 0.077 & 0.799 & $\begin{array}{l}\text { Anions } \\
2.599\end{array}$ & $\begin{array}{c}\mathrm{meq} / \mathrm{l} \\
0.262\end{array}$ & 7.668 \\
\hline
\end{tabular}

Climatic data

Meteorological data were investigated before conducting the experiments by using climwatt and cropwatt programs to calculate reference evapotranspiration and showed in tables 4 and 5 .

ETc calculated as follow:

ETc: crop evapotranspiration

$$
\mathbf{E T c}=\mathbf{E T o} \times \mathbf{K c}
$$

ETo: reference crop evapotranspiration

Kc: crop coefficient

Table 4: Meteorological data and ETo in El Behera governorate

\begin{tabular}{lcccccccc}
\hline & Min Temp. & Max Temp. & Humidity & Wind & Sun & Rad & $\begin{array}{c}\text { Eff. } \\
\text { rain }\end{array}$ & ETo \\
\hline Month & ${ }^{\circ} \mathbf{C}$ & ${ }^{\circ} \mathbf{C}$ & $\mathbf{\%}$ & $\mathbf{k m} / \mathbf{d a y}$ & hours & $\mathbf{M J} / \mathbf{m}^{2} / \mathbf{d a y}$ & $\mathbf{m m}$ & $\mathbf{m m} / \mathbf{d a y}$ \\
\hline Jan. & 5.2 & 19.8 & 52 & 207 & 7.8 & 13.9 & 1 & 2.86 \\
Feb. & 6.6 & 21.8 & 44 & 242 & 8.6 & 17.1 & 1 & 3.89 \\
Mar. & 9.6 & 24.8 & 39 & 277 & 8.9 & 20.1 & 1 & 5.19 \\
Apr. & 13.8 & 30.7 & 31 & 277 & 9.3 & 22.8 & 1 & 6.95 \\
May & 17.5 & 34.5 & 29 & 268 & 10.3 & 25.3 & 0 & 8.05 \\
June & 20.3 & 36.9 & 31 & 277 & 11.2 & 26.9 & 0 & 8.84 \\
July & 21.3 & 37.1 & 36 & 225 & 11.1 & 26.5 & 0 & 8.01 \\
Aug. & 21.4 & 36.8 & 38 & 207 & 10.8 & 25.3 & 0 & 7.48 \\
Sep. & 19.4 & 34.4 & 43 & 216 & 9.9 & 22.1 & 0 & 6.50 \\
Oct. & 16.2 & 30.3 & 46 & 216 & 9.1 & 18.3 & 0 & 5.15 \\
Nov. & 10.6 & 25.5 & 51 & 181 & 8.4 & 14.9 & 0 & 3.55 \\
Dec. & 6.6 & 20.7 & 55 & 199 & 7.9 & 13.3 & 0 & 2.79 \\
\hline
\end{tabular}


Table 5: Kc and ETc. in El-Behara, by using climwatt and cropwatt programs and FAO 56

\begin{tabular}{lcccc}
\hline & \multicolumn{2}{c}{ First season } & \multicolumn{2}{c}{ Second season } \\
Kc & $\mathbf{E T c}$ & Kc & $\begin{array}{c}\text { ETc } \\
\mathbf{m m} / \mathbf{d a y}\end{array}$ \\
\hline January & 0.50 & 1.43 & 0.50 & 1.43 \\
February & 0.50 & 1.945 & 0.50 & 1.945 \\
March & 0.65 & 3.3735 & 0.65 & 3.3735 \\
April & 0.68 & 4.69125 & 0.60 & 4.17 \\
May & 0.68 & 5.43375 & 0.55 & 4.4275 \\
June & 5.967 & 0.50 & 4.42 \\
July & 0.68 & 5.607 & 0.45 & 3.6045 \\
August & 0.70 & 5.236 & 0.45 & 3.366 \\
September & 0.70 & 4.55 & 0.45 & 2.925 \\
October & 0.70 & 3.605 & 0.65 & 3.3475 \\
November & 0.70 & 2.485 & 0.65 & 2.3075 \\
December & 0.70 & 1.953 & 0.65 & 1.8135 \\
\hline
\end{tabular}

Table 6: Irrigation water quintets, dates and intervals in El-Behera governorate

\begin{tabular}{lcccccc}
\hline Month & $\begin{array}{c}\text { Irrigation } \\
\text { requirement } \\
\text { L/ day }\end{array}$ & $\begin{array}{c}\text { First season } \\
\text { Irrigation } \\
\text { duration } \\
\text { hours/day }\end{array}$ & $\begin{array}{c}\text { Irrigation } \\
\text { interval } \\
\text { dayes }\end{array}$ & $\begin{array}{c}\text { Irrigation } \\
\text { requirement } \\
\text { L/day }\end{array}$ & $\begin{array}{c}\text { Second season } \\
\text { Irrigation } \\
\text { duration } \\
\text { hours/day }\end{array}$ & $\begin{array}{c}\text { Irrigation } \\
\text { interval } \\
\text { dayes }\end{array}$ \\
\hline January & 23.32 & 0.25 & 9 & 23.32 & 0.25 & 9 \\
February & 31.72 & 0.34 & 6 & 31.72 & 0.34 & 6 \\
March & 55.02 & 0.60 & 4 & 55.02 & 0.60 & 4 \\
April & 76.51 & 0.83 & 3 & 68.00 & 0.74 & 3 \\
May & 88.61 & 0.96 & 2 & 72.20 & 0.78 & 3 \\
June & 97.31 & 1.06 & 2 & 72.08 & 0.78 & 3 \\
July & 91.44 & 0.99 & 2 & 58.78 & 0.64 & 3 \\
August & 85.39 & 0.93 & 2 & 54.89 & 0.60 & 4 \\
September & 74.20 & 0.81 & 3 & 47.70 & 0.52 & 4 \\
October & 58.79 & 0.64 & 3 & 54.59 & 0.59 & 4 \\
November & 40.53 & 0.44 & 5 & 37.63 & 0.41 & 5 \\
December & 31.85 & 0.35 & 6 & 29.57 & 0.32 & 7 \\
\hline
\end{tabular}

\section{Data of the following parameters were recorded:}

\section{Vegetative growth characteristics}

Five uniform shoots were randomly selected on four main branches of each tree and labeled to record vegetative growth measurements.

\section{Shoot length (cm)}

Shoots length measured for the twenty shoots which selected after the growing seasons of each replicated tree. The length of each shoot "between the points of new growth initiation to the tip of the shoot" was measured at the first week of March and at the last week of November and the difference between these two observations was designated average shoot length. It measured by a ruler and expressed in centimeters $(\mathrm{cm})$.

\section{Number of shoots per meter}

The average number of new shoots per meter of each replicated tree was counted at the last week of November.

\section{Leaf area $\left(\mathrm{cm}^{2}\right)$}

Samples of 20 adult leaves/ treatment were randomly taken from the middle portion of each year's growth of selected shoots to determine leaf blade area at the last week of November, according to equation described by Ahmed and Morsy, (1999) and cited after Shaheen et al., (2011). 


\section{Leaf area $=0.53$ (leaf length $x$ leaf width) +1.66}

\section{Blooming and fruit setting}

\section{Number of inflorescences per shoot:}

Average number of inflorescences per shoots was calculated for the selected shoots for each replicated tree.

\section{Number of perfect flowers per inflorescence:}

Twenty inflorescences at the middle portion of the select shoots were randomly selected from inner and outer portion of the tree canopy to determine the number of perfect flowers per inflorescence.

\section{Sex expression:}

Sex expression calculated according the next equation

$$
\text { Sex expression }=\frac{\text { Number of perfect flowers }}{\text { Number of total flowers }} \times 100
$$

\section{Initial fruit set}

Initial fruit set was calculated after twenty days of pollination according the next equation.

$$
\text { Initial fruit set }=\frac{\text { Number of Initial fruit }}{\text { Number of perfect flowers }} \times 100
$$

\section{Statistical analysis}

Results of this study were exposed to proper statistical analysis of variance for a split plot design with two factors "irrigation treatments were allocated as main plot and spraying Lithovitas sub plot" using statistix computer program (Anonymous, 2008) with three replicates. Each replicate's value was the average of two trees values. Duncan's multiple range tests were used to compare between means. Alphabetical letters in the column are significantly different at (0.05) level (Duncan, 1955). The same trees were used throughout both of experimental seasons.

\section{Results}

\section{Vegetative growth}

\section{Shoot length}

Data in table (7) appear the significant effects on the values of shoot length of Manzanello olive cultivar due to different Lithovit and irrigation levels in both seasons.

Spraying Lithovit at 6 and $2 \mathrm{~g} / \mathrm{L}$ exhibited the highest shoot length values of Manzanello (19.5 \& $17.2 \mathrm{~cm}$ ) olives compared with the other treatments in the first and second seasons, respectively. In addition, $100 \%$ of ETc irrigation achieved the highest significant values of shoot length of Manzanello $(24.2 \& 21.9 \mathrm{~cm})$ olive cultivar compared with the other treatments in the first and second seasons, respectively.

Concerning the interaction between spraying Lithovit and irrigation, it's quite clear that spraying Lithovit at $6 \& 2 \mathrm{~g} / \mathrm{L}$ with irrigation at $100 \%$ of ETc had the maximum values of shoot length of Manzanello $(30.7 \& 24.0 \mathrm{~cm}$ ) olive cultivar compared with the other treatments in the first and second seasons, respectively.

\section{Shoots number/meter}

Table (8) clarifies the significant effects on shoots number / meter values of Manzanello olive cultivar among spraying Lithovit and irrigation levels in the first and second seasons.

Spraying Lithovit at $6 \mathrm{~g} / \mathrm{L}$ concentration optimized the values of shoots number/ meter of Manzanello (27.71 \& 36.67) olive cultivar compared with the other treatments in the first and second 
seasons, respectively. Besides, irrigation at $100 \%$ of ETc revealed the highest significant values of new shoots number/ meter of Manzanello (26.66 \& 34.75) olive cultivar compared with the other treatments in the first and second seasons, respectively.

Concerning the interactions, it is quite clear that spraying Lithovit at $6 \mathrm{~g} / \mathrm{L}$ and irrigation at $100 \%$ of ETc maximized shoots number/ meter values of Manzanello (31.00 \& 42.67) and Manzanello (30.67 $\& 29.00$ )olive cultivars compared with the other treatments in the first and second seasons, respectively.

Table 7: Effect of irrigation and spraying Lithovit levels on shoot length of Manzanello olives during 2017 and 2018 seasons

\begin{tabular}{|c|c|c|c|c|c|c|c|c|c|c|c|}
\hline \multicolumn{4}{|c|}{ Parameter } & \multicolumn{7}{|c|}{ Shoot length (cm) } & \\
\hline & & \multicolumn{5}{|c|}{2017} & \multicolumn{5}{|c|}{2018} \\
\hline \multicolumn{2}{|c|}{ Treatments } & \multicolumn{4}{|c|}{ Lithovit rate } & \multirow{2}{*}{$\begin{array}{c}\text { Irrigation } \\
\text { Mean }\end{array}$} & \multicolumn{4}{|c|}{ Lithovit rate } & \multirow{2}{*}{$\begin{array}{c}\text { Irrigation } \\
\text { Mean }\end{array}$} \\
\hline & & $0 \mathrm{~g} / \mathrm{L}$ & $2 \mathrm{~g} / \mathrm{L}$ & $4 \mathrm{~g} / \mathrm{L}$ & $6 \mathrm{~g} / \mathrm{L}$ & & $0 \mathrm{~g} / \mathrm{L}$ & $2 \mathrm{~g} / \mathrm{L}$ & $4 \mathrm{~g} / \mathrm{L}$ & $6 \mathrm{~g} / \mathrm{L}$ & \\
\hline \multirow{6}{*}{ 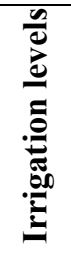 } & $100 \%$ & 18.5 & 21.4 & 26.2 & 30.7 & 24.2 & 21.3 & 24.0 & 23.2 & 19.0 & 21.9 \\
\hline & $100 \%$ & d & $\mathrm{c}$ & $\mathrm{b}$ & $\mathrm{a}$ & A & $\mathrm{b}$ & $\mathrm{a}$ & $\mathrm{a}$ & $\mathrm{c}$ & A \\
\hline & & 13.4 & 18.3 & 18.4 & 18.6 & 17.2 & 15.8 & 17.6 & 15.9 & 15.6 & 16.2 \\
\hline & $15 \%$ & $\mathrm{e}$ & d & d & d & B & d & $\mathrm{c}$ & d & $\mathrm{d}$ & B \\
\hline & $50 \%$ & 6.3 & 8.2 & 8.2 & 9.1 & 8.0 & 7.3 & 9.9 & 10.4 & 11.6 & 9.8 \\
\hline & $50 \%$ & $\mathrm{~g}$ & fg & fg & $\mathrm{f}$ & $\mathrm{C}$ & $\mathrm{g}$ & $\mathrm{f}$ & ef & $\mathrm{e}$ & $\mathrm{C}$ \\
\hline \multirow{2}{*}{\multicolumn{2}{|c|}{ Lithovit Mean }} & 12.2 & 14.4 & 15.3 & 17.0 & & 13.7 & 16.7 & 14.1 & 13.5 & \\
\hline & & $\mathrm{C}$ & $\mathrm{B}$ & $\mathrm{B}$ & A & & $\mathrm{B}$ & A & B & $\mathrm{B}$ & \\
\hline
\end{tabular}

Means followed by the same letter/s in each row, column or interaction are not significantly different at $5 \%$ level.

Table 8: Effect of irrigation and spraying Lithovit levels on shoots number /meter of Manzanello olives during 2017 and 2018 seasons

\begin{tabular}{|c|c|c|c|c|c|c|c|c|c|c|c|}
\hline \multirow{4}{*}{\multicolumn{2}{|c|}{$\begin{array}{l}\text { Parameter } \\
\text { Treatments }\end{array}$}} & \multicolumn{10}{|c|}{ Shoot number/meter } \\
\hline & & \multicolumn{5}{|c|}{2017} & \multicolumn{5}{|c|}{2018} \\
\hline & & \multirow[b]{2}{*}{$0 \mathrm{~g} / \mathrm{L}$} & \multicolumn{2}{|c|}{ Lithovit rate } & \multirow[b]{2}{*}{$6 \mathrm{~g} / \mathrm{L}$} & \multirow{2}{*}{$\begin{array}{c}\text { Irrigation } \\
\text { Mean }\end{array}$} & \multirow[b]{2}{*}{$0 \mathrm{~g} / \mathrm{L}$} & \multicolumn{2}{|c|}{ Lithovit rate } & \multirow[b]{2}{*}{$6 \mathrm{~g} / \mathrm{L}$} & \multirow{2}{*}{$\begin{array}{c}\text { Irrigation } \\
\text { Mean }\end{array}$} \\
\hline & & & $2 \mathrm{~g} / \mathrm{L}$ & $4 \mathrm{~g} / \mathrm{L}$ & & & & $2 \mathrm{~g} / \mathrm{L}$ & $4 \mathrm{~g} / \mathrm{L}$ & & \\
\hline$\frac{\infty}{0}$ & $100 \%$ & 20.33 & 26.33 & 29.00 & 31.00 & 26.66 & 28.00 & 32.00 & 39.33 & 42.67 & 34.75 \\
\hline e् & $100 \%$ & e & $\mathrm{c}$ & $\mathrm{b}$ & $\mathrm{a}$ & A & $d-f$ & $\mathrm{c}$ & $\mathrm{b}$ & $\mathrm{a}$ & A \\
\hline $\bar{\Xi}$ & $75 \%$ & 17.67 & 22.00 & 26.83 & 27.67 & 23.54 & 25.67 & 26.00 & 31.67 & 38.33 & 30.42 \\
\hline 氙 & $15 \%$ & $\mathrm{f}$ & e & $\mathrm{c}$ & $\mathrm{bc}$ & $\mathrm{B}$ & e-g & ef & $\mathrm{cd}$ & $\mathrm{b}$ & $\mathrm{B}$ \\
\hline .00 & & 13.77 & 18.33 & 20.87 & 24.47 & 17.77 & 22.00 & 25.00 & 28.66 & 29.00 & 26.17 \\
\hline$\Xi$ & $50 \%$ & $\mathrm{~g}$ & $\mathrm{f}$ & $\mathrm{e}$ & $\mathrm{d}$ & $\mathrm{C}$ & $\mathrm{g}$ & fg & $c-f$ & c-e & $\mathrm{C}$ \\
\hline \multirow{2}{*}{\multicolumn{2}{|c|}{ Lithovit Mean }} & 17.26 & 22.22 & 25.57 & 27.71 & & 25.22 & 27.67 & 32.22 & 36.67 & \\
\hline & & $\mathrm{D}$ & $\mathrm{C}$ & $\mathrm{B}$ & A & & $\mathrm{D}$ & $\mathrm{C}$ & B & A & \\
\hline
\end{tabular}

Means followed by the same letter/s in each row, column or interaction are not significantly different at 5\% level.

\section{Leaf area $\left(\mathrm{cm}^{2}\right)$}

Data in table (9) expose the significant effects on leaf area of Manzanello olive cultivar due to different Lithovit spray and irrigation levels in the first and second seasons.

Spraying Lithovit at $6 \mathrm{~g} / \mathrm{L}$ concentration increased leaf area values $\left(4.45 \& 5.72 \mathrm{~cm}^{2}\right)$ olive cultivar compared with the other treatments in the first and second seasons, respectively. Likewise, 100 $\%$ of ETc irrigation recorded the highest significant leaf area $\left(4.58 \& 6.13 \mathrm{~cm}^{2}\right)$ olives compared with the other treatments in the first and second seasons, respectively. In addition, the interaction clears that trees which sprayed with Lithovit at $6 \mathrm{~g} / \mathrm{L}$ and irrigated at $100 \%$ of ETc maximized leaf area values $\left(4.83 \& 6.80 \mathrm{~cm}^{2}\right)$ olive cultivar compared with the other treatments in the first and second seasons, respectively.

\section{Blooming and fruit setting}

\section{Inflorescences number/ shoot}

As shown in table (10), the values of inflorescences number of Manzanello olive cultivar were significantly affected by all treatments in the first and second seasons. 
Spraying with Lithovit at $2 \mathrm{~g} / \mathrm{L}$ gave the highest values of inflorescences number of Manzanello (6.88 \& 5.39) olives compared with the other treatments in first season and second seasons, respectively. Likewise, irrigation at $75 \%$ of ETc significantly increased perfect flowers of Manzanello (6.41 \& 6.04) olive cultivar compared with the other treatments in the first and second seasons, respectively.

The interaction between irrigation levels and Lithovit showed that the highest values of inflorescences number were noticed with $75 \%$ of ETc irrigation with spraying Lithovit at $2 \mathrm{~g} / \mathrm{L}$ of Manzanello ( $7.83 \&$ 4.17) olive cultivar compared with the other treatments in the first and second seasons, respectively.

Table 9: Effect of irrigation and spraying Lithovit levels on Leaf area $\left(\mathrm{cm}^{2}\right)$ of Manzanello olives during 2017 and 2018 seasons

\begin{tabular}{|c|c|c|c|c|c|c|c|c|c|c|c|}
\hline \multicolumn{2}{|c|}{ Parameter } & \multicolumn{10}{|c|}{ Leaf area $\left(\mathrm{cm}^{2}\right)$} \\
\hline \multirow{2}{*}{\multicolumn{2}{|c|}{ Treatments }} & \multicolumn{5}{|c|}{2017} & \multicolumn{5}{|c|}{2018} \\
\hline & & \multirow[b]{2}{*}{$0 \mathrm{~g} / \mathrm{L}$} & \multicolumn{3}{|c|}{ Lithovit rate } & \multicolumn{2}{|l|}{ Irrigation } & \multicolumn{3}{|c|}{ Lithovit rate } & \multirow{2}{*}{ Irrigation } \\
\hline & & & $2 \mathrm{~g} / \mathrm{L}$ & $4 \mathrm{~g} / \mathrm{L}$ & $6 \mathrm{~g} / \mathrm{L}$ & Mean & $0 \mathrm{~g} / \mathrm{L}$ & $2 \mathrm{~g} / \mathrm{L}$ & $4 \mathrm{~g} / \mathrm{L}$ & $6 \mathrm{~g} / \mathrm{L}$ & \\
\hline$\frac{n}{0}$ & & 4.27 & 4.51 & 4.70 & 4.83 & 4.58 & 50.33 & 6.12 & 6.28 & 6.80 & 6.13 \\
\hline 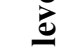 & $100 \%$ & $d-f$ & $b-d$ & $a b$ & $\mathrm{a}$ & $\mathrm{A}$ & c-e & $\mathrm{a}-\mathrm{c}$ & $\mathrm{ab}$ & $\mathrm{a}$ & A \\
\hline $\bar{\Xi}$ & & 3.65 & 3.99 & 4.14 & 4.32 & 4.03 & 4.62 & 7.75 & 5.23 & 5.55 & 5.04 \\
\hline 急 & $75 \%$ & hi & fg & ef & c-e & B & e-g & d-g & $d-f$ & $b-d$ & $\mathrm{~B}$ \\
\hline 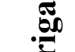 & $50 \%$ & 3.30 & 3.67 & 4.01 & 4.21 & 3.80 & 4.13 & 4.14 & 4.53 & 4.80 & 4.40 \\
\hline & $50 \%$ & $\mathrm{j}$ & $\mathrm{h}$ & fg & $d-f$ & $\mathrm{C}$ & $\mathrm{g}$ & $\mathrm{g}$ & fg & d-g & $\mathrm{C}$ \\
\hline Lith & it Mean & 3.74 & 4.06 & 4.28 & 4.45 & & 4.70 & 5.00 & 4.35 & 5.72 & \\
\hline & I Mean & $\mathrm{D}$ & $\mathrm{C}$ & B & A & & $\mathrm{C}$ & $\mathrm{BC}$ & $\mathrm{AB}$ & A & \\
\hline
\end{tabular}

Means followed by the same letter/s in each row, column or interaction are not significantly different at $5 \%$ level.

Table 10: Effect of irrigation and spraying Lithovit levels on inflorescence number/shoot of Manzanello olives during 2017 and 2018 seasons

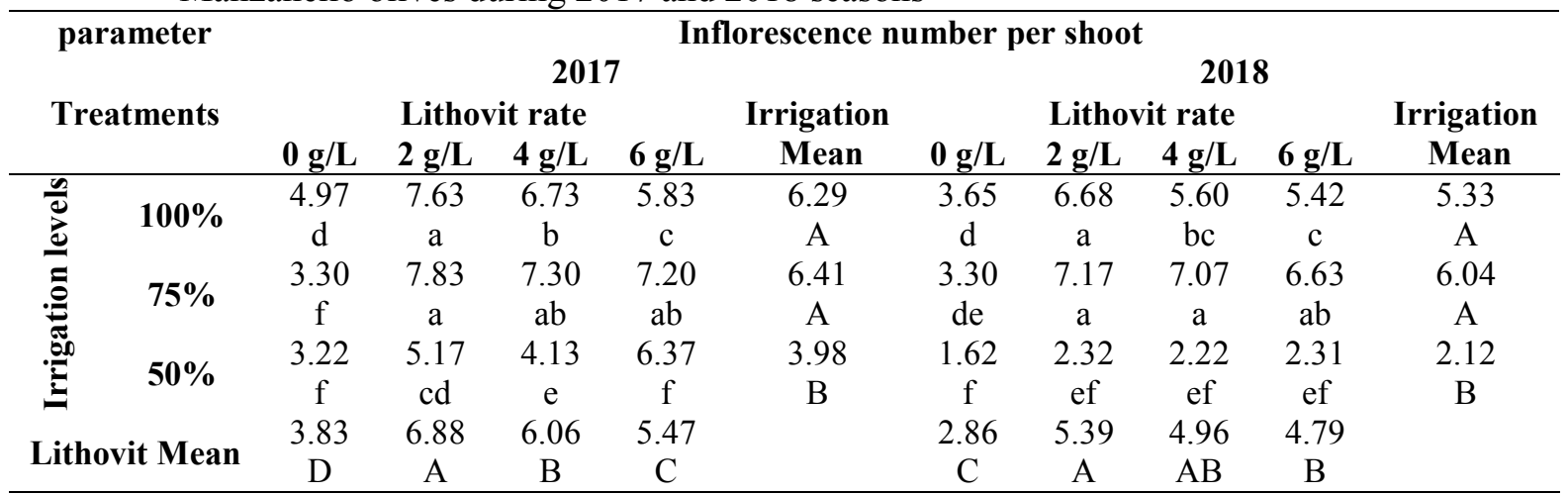

Means followed by the same letter/s in each row, column or interaction are not significantly different at $5 \%$ level.

\section{Perfect flowers / inflorescence}

Table (11) indicates that perfect flowers of Manzanello olive cultivar were significantly affected with all treatments in both seasons .

Spraying with Lithovit at $2 \mathrm{~g} / \mathrm{L}$ showed the highest values of perfect flowers of Manzanello (14.94 $\&$ 7.86) olive cultivar compared with the other treatments in the first and second seasons, respectively. Additionally, $75 \%$ of ETc irrigation significantly increased perfect flowers of Manzanello (13.91 \& 5.15) olive cultivar compared with the other treatments in the first and second seasons, respectively .

The interaction between irrigation levels and Lithovit concentrations showed that the best values of perfect flowers were noticed with spraying Lithovit at $2 \mathrm{~g} / \mathrm{L}$ and $75 \%$ of ETc irrigation level of Manzanello (17.03 \& 10.26) olives compared with other treatments in the first and second seasons, respectively.

\section{Sex expression}

Data presented in table (12) indicate that spraying Lithovit at $4 \& 2 \mathrm{~g} / \mathrm{L}$ gave the highest significant values of sex expression ( $83.45 \& 70.48 \%$ ) with non-significance between it and $2 \mathrm{~g} / \mathrm{L}(82.65 \%)$ compared with other treatments in the first season. Besides, the highest significant value of sex 
expression was gained by $75 \& 100 \%$ of ETc irrigation level $(77.76 \& 68.25 \%)$ in the first and second seasons, respectively.

Concerning the interaction, it's obvious that trees which received $4 \mathrm{~g} / \mathrm{L}$ of Lithovit and $100 \%$ of ETc irrigation have the highest significant sex expression (91.55\%) compared with other treatments in the first season while trees which received $4 \mathrm{~g} / \mathrm{L}$ of Lithovit and $75 \%$ of ETc irrigation have the highest significant sex expression (76.92\%) in the second season.

Table 11: Effect of irrigation and spraying Lithovit levels on perfect flowers number of Manzanello olives during 2017 and 2018 seasons.

\begin{tabular}{|c|c|c|c|c|c|c|c|c|c|c|c|}
\hline \multicolumn{2}{|c|}{ Parameter } & \multicolumn{10}{|c|}{ Number of Perfect flowers / inflorescences } \\
\hline \multirow{3}{*}{\multicolumn{2}{|c|}{ Treatments }} & \multirow{2}{*}{\multicolumn{4}{|c|}{ Lithovit rate }} & & & \multicolumn{3}{|c|}{2018} & \multirow[b]{2}{*}{ Irrigation } \\
\hline & & & & & & \multicolumn{2}{|l|}{ Irrigation } & \multicolumn{2}{|c|}{ Lithovit rate } & \multirow[b]{2}{*}{$6 \mathrm{~g} / \mathrm{L}$} & \\
\hline & & $0 \mathrm{~g} / \mathrm{L}$ & $2 \mathrm{~g} / \mathrm{L}$ & $4 \mathrm{~g} / \mathrm{L}$ & $6 \mathrm{~g} / \mathrm{L}$ & Mean & $0 \mathrm{~g} / \mathrm{L}$ & $2 \mathrm{~g} / \mathrm{L}$ & $4 \mathrm{~g} / \mathrm{L}$ & & $\begin{array}{l}\text { Mean } \\
658\end{array}$ \\
\hline$\frac{n}{0}$ & $100 \%$ & $\begin{array}{c}9.50 \\
\text { ef }\end{array}$ & 14.67 & 13.80 & $\begin{array}{c}6.93 \\
\sigma\end{array}$ & $\begin{array}{c}11.23 \\
\mathrm{~B}\end{array}$ & 5.84 & 7.75 & 7.06 & $\begin{array}{c}5.66 \\
\text { ef }\end{array}$ & $\begin{array}{c}6.58 \\
B\end{array}$ \\
\hline$\stackrel{\Xi}{\Xi}$ & & 10.60 & 17.03 & 15.40 & 12.60 & $\begin{array}{c}\mathrm{D} \\
13.91\end{array}$ & 5.90 & 10.26 & 8.67 & 7.76 & $\begin{array}{l}\mathrm{D} \\
8.15\end{array}$ \\
\hline 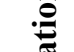 & $75 \%$ & de & a & $\mathrm{ab}$ & $c d$ & A & $\mathrm{e}$ & $\mathrm{a}$ & $\mathrm{d}$ & bd & A \\
\hline 60 & & 7.93 & 10.57 & 9.30 & 7.37 & 8.80 & 4.76 & 7.39 & 6.23 & 5.49 & 5.97 \\
\hline$=$ & $50 \%$ & fg & de & ef & fg & $\mathrm{C}$ & $\mathrm{f}$ & $\mathrm{c}$ & de & ef & $\mathrm{C}$ \\
\hline $\mathrm{Ii}$ & it Mon & 9.34 & 14.09 & 12.84 & 8.97 & & 5.50 & 8.47 & 7.32 & 6.30 & \\
\hline & t Mean & $\mathrm{C}$ & A & B & $\mathrm{C}$ & & $\mathrm{D}$ & A & B & $\mathrm{C}$ & \\
\hline
\end{tabular}

Means followed by the same letter/s in each row, column or interaction are not significantly different at $5 \%$ level.

Table 12: Effect of irrigation and spraying Lithovit levels on sex expression of Manzanello olives during 2017 and 2018 seasons

\begin{tabular}{|c|c|c|c|c|c|c|c|c|c|c|c|}
\hline \multicolumn{2}{|c|}{ Parameter } & \multicolumn{10}{|c|}{ Sex expression (\%) } \\
\hline & & \multicolumn{5}{|c|}{2017} & \multicolumn{5}{|c|}{2018} \\
\hline \multirow{2}{*}{\multicolumn{2}{|c|}{ Treatments }} & \multirow[b]{2}{*}{$0 \mathrm{~g} / \mathrm{L}$} & \multicolumn{3}{|c|}{ Lithovit rate } & \multicolumn{2}{|l|}{ Irrigation } & \multicolumn{3}{|c|}{ Lithovit rate } & \multirow{2}{*}{$\begin{array}{c}\text { Irrigation } \\
\text { Mean }\end{array}$} \\
\hline & & & $2 \mathrm{~g} / \mathrm{L}$ & $4 \mathrm{~g} / \mathrm{L}$ & $6 \mathrm{~g} / \mathrm{L}$ & Mean & $0 \mathrm{~g} / \mathrm{L}$ & $2 \mathrm{~g} / \mathrm{L}$ & $4 \mathrm{~g} / \mathrm{L}$ & $6 \mathrm{~g} / \mathrm{L}$ & \\
\hline \multirow{5}{*}{ 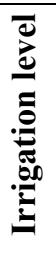 } & $100 \%$ & 70.88 & 83.93 & 91.55 & 54.85 & 75.29 & 61.92 & 66.84 & 63.62 & 58.02 & 68.25 \\
\hline & & 67.42 & $\begin{array}{c}\mathrm{D} \\
86.23\end{array}$ & 83.48 & $\begin{array}{c}\mathrm{t} \\
73.92\end{array}$ & $\begin{array}{c}\mathrm{ab} \\
77.76\end{array}$ & $\begin{array}{c}\mathrm{f} \\
56.87\end{array}$ & $\begin{array}{c}d \\
73.39\end{array}$ & $\begin{array}{c}\mathrm{e} \\
70.68\end{array}$ & $\begin{array}{c}\mathrm{g} \\
76.92\end{array}$ & $\begin{array}{c}\mathrm{a} \\
67.11\end{array}$ \\
\hline & $75 \%$ & $\mathrm{e}$ & $\mathrm{b}$ & $\mathrm{b}$ & $\mathrm{cd}$ & $\mathrm{a}$ & $\mathrm{g}$ & $\mathrm{b}$ & $\mathrm{c}$ & $\mathrm{a}$ & $\mathrm{a}$ \\
\hline & $50 \%$ & 70.33 & 77.79 & 75.33 & 66.71 & 72.54 & 85.34 & 71.20 & 66.54 & 67.49 & 62.60 \\
\hline & $50 \%$ & de & $\mathrm{c}$ & $\mathrm{cd}$ & $\mathrm{e}$ & b & $\mathrm{g}$ & $\mathrm{bc}$ & $\mathrm{d}$ & d & $\mathrm{b}$ \\
\hline \multirow{2}{*}{\multicolumn{2}{|c|}{ Lithovit Mean }} & 69.45 & 82.65 & 83.45 & 65.16 & & 59.04 & 70.48 & 66.95 & 67.47 & \\
\hline & & $\mathrm{b}$ & $\mathrm{a}$ & $\mathrm{a}$ & $\mathrm{c}$ & & $\mathrm{c}$ & $\mathrm{a}$ & $\mathrm{b}$ & $\mathrm{b}$ & \\
\hline
\end{tabular}

Means followed by the same letter/s in each row, column or interaction are not significantly different at $5 \%$ level.

\section{Initial fruit set}

Table (13) illustrates that spraying Lithovit at $2 \mathrm{~g} / \mathrm{L}$ gave the highest values of initial fruit set of Manzanello (3.69 \& 2.67) olive cultivar compared with the other treatments in the first and second seasons, respectively .

Table 13: Effect of irrigation and spraying Lithovit levels on initial fruit set of Manzanello olives during 2017 and 2018 seasons

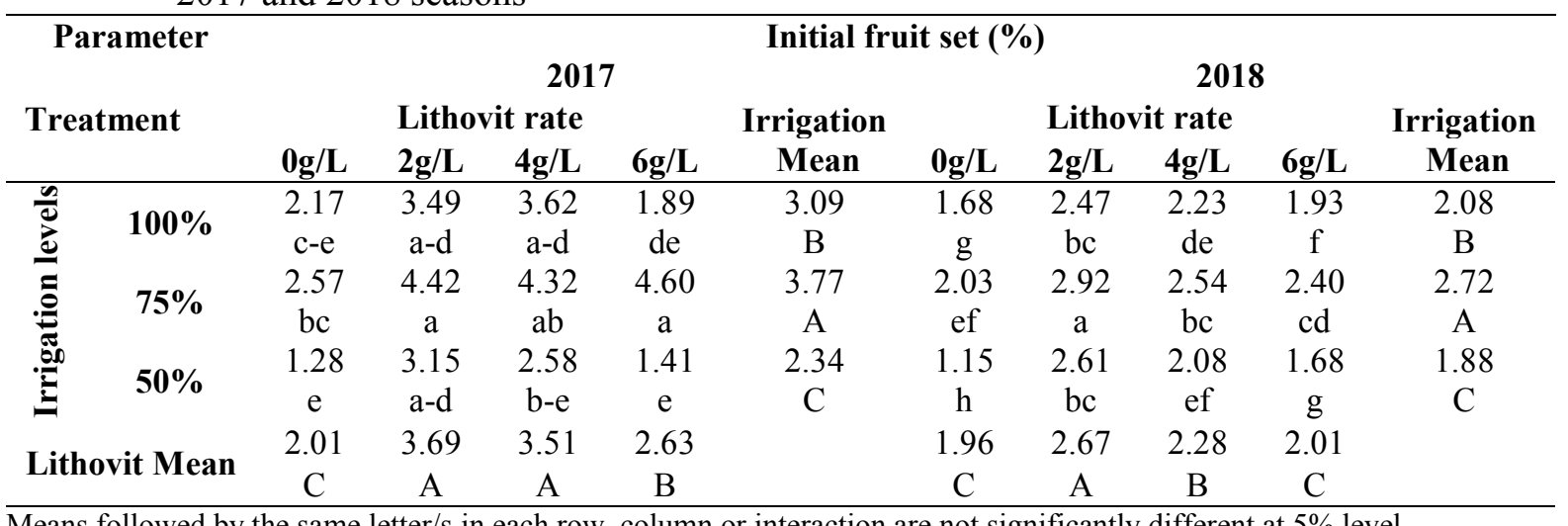

Means followed by the same letter/s in each row, column or interaction are not significantly different at $5 \%$ level. 
Moreover, irrigation with $75 \%$ of ETc significantly increased initial fruit set of Manzanello (3.77 $\& 2.72$ ) olives compared with the other treatments in the first and second seasons, respectively .

The interaction between irrigation and spraying Lithovit levels showed that the highest values of initial fruit set were noticed with $75 \%$ of ETc irrigation levels and spraying with Lithovit at $6 \& 2 \mathrm{~g} / \mathrm{L}$ for Manzanello ( $4.60 \&$ 2.92) cultivar compared with the other treatments in the first and second seasons, respectively.

\section{Discussion}

Results show that growing seasons affected on olive growth, blooming and fruit setting due to alternative bearing. The values of shoot length, number of shoots, leaf area and horticultural fruit set in the second season were higher than those in first seasons and vice versa for perfect flowers, inflorescences no., sex expression and initial fruit set.

\section{Effect of irrigation levels on olive growth, blooming and fruit setting}

Results indicate that water stress is a vital factor limiting olive cultivation in Mediterranean basin; also it can impair the performance of olives growth, blooming and fruit setting.

Concerning vegetative growth, applying irrigation at $100 \%$ of ETc stimulated vegetative growth and increased shoot length, shoots number in the first and the second seasons. Moreover, leaf area was increased in second season. Irrigation at $50 \%$ of ETc led to decrease shoot length, shoots number and leaf area in the both seasons. These results agree with Arzani and Arji, (2000), Guerfel et al. (2009), Shaheen et al. (2011) and Dobiea et al. (2019). The negative effect of prolonged water stress may lead to reduce the plant-cell's water potential and turgor pressure which affects the rate of cell expansion and ultimate cell size. Drought doesn't only affect physiological processes but also biochemical processes. Thus, drought stress caused reduction in vegetative growth parameters.

Blooming and fruit setting were affected by different irrigation levels. The most promising level "75\% of ETc" showed the highest values of perfect flowers, inflorescences number/ shoot and initial fruit set in the first and the second seasons in addition to sex expression in second season. Irrigation at $100 \%$ of ETc increased vegetative growth, which led to decrease blooming and fruit setting. Moreover, prolonged water stress " $50 \%$ of ETc" led to decrease vegetative, assimilation of the leaf so it impaired blooming and fruit setting. These results are in harmony with Lavee and wonder (1992), Bignami et al. (1995), Wu-ShuBiao (2002), Vrhovnik (2004), Rapoport et al. (2011) and Dobiea et al. (2019).

\section{Effect of spraying Lithovit on olives growth, Blooming and fruit setting}

Concerning vegetative growth, results indicate that spraying Lithovit $(6 \mathrm{~g} / \mathrm{L})$ Stimulated vegetative growth and increased shoots number, leaves area in the first and the second seasons in addition to shoot length in the first season. These results agree with Abd El-Aal and Eid, (2018) and Dobiea et al. (2019).

Regarding blooming, spraying Lithovit $(2 \mathrm{~g} / \mathrm{L})$ gave the highest values of perfect flower, sex expression, initial fruit set and horticultural fruit set. These results agree with Abdelghafar et al. (2016) and Dobiea et al. (2019).

These parameters could be improved because of enhancing physiological, biological, assimilation and dissimilation process, because of elevated $\mathrm{CO}_{2}$ in intercellular compartment and on leave surface which lead to close stomata, decrease transpiration rate and enhance photosynthesis in addition to water use efficiency according to Kumar et al. (2013). Also, spraying Lithovit may play an effective role because of its components (Abdel Nabi et al., 2017 and Ghatas et al., 2018). Physiological and chemical analysis will clarify the actual reason of these effects.

\section{Conclusion}

At the end of this research we recommend application of spraying Lithovit at $2 \mathrm{~g} / \mathrm{L}$ to increase perfect flowers, sex expression, initial fruit set and horticultural fruit set of Manzanello olives. Furthermore, irrigation at $75 \%$ of ETc was recommended to balance between vegetative, blooming and productivity. Moreover, it showed the highest significant values of perfect flowers, inflorescences number and initial fruit set. 
Concerning the interaction between irrigation and spraying Lithovit it could be concluded that perfect flowers, initial fruit set improved and showed the highest values by spraying Lithovit at $2 \mathrm{~g} / \mathrm{L}$ with irrigation at $75 \%$ of ETc.

Moreover we could utilise the variance effect of different irrigation levels and spraying Lithovit concentrations to reduse the hardness of alternative bearing, via spraying $2 \mathrm{~g} / \mathrm{L}$ of Lithovit and $75 \%$ of ETc irrigation level in the OFF year. On the other hand we recommend spraying Lithovit at 4 or $6 \mathrm{~g} / \mathrm{L}$ with $100 \%$ of ETc irrigation level to improve the aspects of vegetative growth in the ON year.

Finally, we caution against exposing olive trees to severe water stress $(50 \%$ of ETc).

\section{Acknowledgement}

I find it is a golden moment to reiterate my indebtedness and deep sense of regards to Academic of scientific research and technology which funded this research. It was a part of master study in Pomology at Horticulture department, Faculty of Agriculture, Benha University, Egypt.

\section{References}

Abdel Nabi, H., K. Dawa; E. El-Gamily and Y. Imryed, 2017. Effect of magnetic water, foliar application with nano material and nitrogen levels on productivity and quality of head lettuce. Int. J. Adv. Res. Biol. Sci., 4 (5): 171-181.

Abdelal, M. and S. Eid, 2018. Effect of foliar spray with Lithovit and amino acids on growth, bio constituents, anatomical and yield features of soybean plant. 4th International Conference on Biotechnology Applications in Agriculture (ICBAA), Benha University, Moshtohor and Hurghada, 4-7 April 2018, Egypt

Abdelghafar, M. S., M. AlAbd; A. Helaly and A. Rashwan, 2016. Foliar Application of Lithovit and Rose Water as Factor for Increasing Onion Seed Production. Nat. Sci., 14 (3), 53-61

Ahmed, F. and M. Morsy, 1999. A new method for measuring leaf area in different fruit species. Minia J. of Agric Res. Develop, 19, 97-105.

Ainsworth, E. and A. Rogers, 2007. The response of photosynthesis and stomatal conductance to rising [CO2]: mechanisms and environmental interactions J. Plant, Cell \& Environment. 30, 258-270.

Anonymous, 2008. Statistix 9 User's Manual. Analytical Software, Tallahassee, FL. 454 p.

Arzani, K. and I. Arji, 2000. The effect of water stress and deficit irrigation on young potted olive cv 'Local-Roghani-Roodbar'. Acta Horticulturae 537 (2), 879-885.

Asik, S., U. Kaya; G. Camoglu; E. Akkuzu; H. Olmez and M. Avci, 2014. Effect of different irrigation levels on the yield and traits of Memecik olive trees (Olea europaea L.) in the Aegean coastal region of Turkey. Journal of Irrigation and Drainage Engineering; 140 (8), 4401- 4025.

Bignami, G., S. Natali and C. Cammilli, 1995. Postharvest irrigation of earli peach cultivars.21st Convegno peschicolo Ravenna, Ittaly, Camere di Cammercio industria Artigianato Agricolture di Ravenna e forli.,235-245.

Bunce, J. A., 2003. Carbon dioxide effects on stomatal responses to the environment and water use by crops under field conditions. J. Oecologia, 140, 1-10

Carmen, B., R. Sumalan; S. Gadea and S. Vatca, 2014. Physiological Indicators Study Involved in Productivity Increasing in Tomato. J. Pro. Environment, 7, 218 - 224.

Chartzoulakis, K., A. Bosabalidis; A. Patakas and S. Vemmos, 2000. Effects of water stress on water relations, gas exchange and leaf structure of olive tree. Acta Horticulturae, 537, 241-247.

Dobiea, I. M., El-Badawy, H. E. M., El-Gioushy,S. F. and Hegazy, A. A. H. , 2019. Effect of Spraying Dolomite Nano-Particles on Growth, Flowering and Fruit Setting of Picual Olive (Olea europaea L.) Cultivar under Water Stress Conditions. 5th International Conference on Biotechnology Applications in Agriculture (ICBAA), Benha University, Moshtohor and Hurghada, 8-11 April 2020, Egypt.

Duncan, D.B., 1955. Multiple range and multiple F tests.Biometrics, 11:1 - 24.

Ghatas, Y. and Y. Mohamed, 2018. Influence of Mineral, Micro-nutrients and Lithovit on Growth, Oil Productivity and Volatile Oil Constituents of Cymbopogon citruts L. Plants. Middle East J. Agric. Res., 7 (1), 162-174. 
Guerfel, M., O. Baccouri; D. Boujnah; W. Chai and M. Zarrouk, 2009. Impacts of water stress on gas exchange, water relations, chlorophyll content and leaf structure in the two main Tunisian olive (Olea europaea L.) cultivars. Scient. Hort., 119: 257-263.

Kumar, V., V. Guleria and S. Yadav , 2013. Gold NANO particle exposure induces growth and yield enhancement in Arabidopsis thaliana. Science of the Total Environment, 641 (1), 462-468.

Lavee, S. and M. wonder, 1992. Factors affecting the nature of soil Accumulation in fruit of olive. J. Hort. Sci., 66 (5), 583- 591

Lavee, S., M. Nashof; M. Wonder and H. Harchemesh, 1990. The effect of complementary irrigation adds to old olive trees cv Souri on fruit characteristics, yield and oil production. Adv. Hort. Sci., 4 (3), 135-138.

Rapoport, H., O. Perez-Priego; F. Orgaz and P. Martins, 2011. Water deficit effects during olive tree inflorescence and flower development. Acta Horticulturae. (888), 157-162.

Shaheen, M., A. Hegaz and I. Hmmam, 2011. Effect of Water Stress on Vegetative Characteristics and Leaves Chemical Constituents of Some Transplants Olive Cultivars. J. Agric. \& Environ. Sci., 11 (5), 663-670.

Tangu, N. A., 2014. Effects on Plant Morphology of drought in olive. Turkish Journal of Agricultural and Natural Sciences, 1, 900:904.

Vrhovnik, I., 2004. Consequences of the drought in 2003 on olive groves in Slovenian Istria.Zbornikreferatov-1-Slovenskega-sadjarskega-kongresa-z-ednarodnodelezbo Krsko Slovenia 24-26 marec 2004 Del 2, 811-817.

Wu-ShuBiao; G. Collins and M. Sedgley, 2002. Sexual compatibility within and between olive cultivars. Journal of Horticultural Science and Biotechnology, 77 (6), 665-673.

Xiloyannis C., B. Dichio, V. Nuzzo and G.Celano, 1999. Defense strategies of olive against water stress. Acta hortic. 4 (3): 423-426 